ISSN. 2775-4324 (Online)

Journal of Physical Activity and Sports

Volume 2, Nomor 3, Desember 2021, 322-328

\title{
Penerapan Model Pembelajaran Cooperative Learning Tipe Group Investigation Dan Problem Based Learning Terhadap Hasil Belajar Kognitif Materi Bulutangkis Siswa Kelas X SMA Negeri 5 Semarang
}

\author{
Satrio Sembodo \\ Universitas PGRI Semarang, Jl. Gajah Raya No.40, Semarang, 50166, Indonesia \\ satriosembodo99@gmail.com
}

\begin{abstract}
Abstrac
The background obtained, the applied learning has not been able to improve learning outcomes, especially the material for the forehand lob in the badminton game, this study uses a quantitative research method using an experimental approach, the design used in this study is a quasi-experimental design, the population in this study is Class X students of SMA Negeri 5 Semarang, the sampling technique used random sampling. The sample in the study was obtained by class X IPS 1 as experimental class 1 with a total of 30 students and class X IPS 2 as class experiment 2 with a total of 30 students. Data analysis used validity test, reliability test, normality test, homogeneity test, and t test (comparative test). Based on the results of the research and discussion, it was found that learning outcomes of badminton forehand overhead lob by applying the group investigation type cooperative learning model obtained an average value of 69 and the application of the problem based learning model obtained an average result of 76 . cooperative learning learning type group investigation and problem based learning based on an average of 7 points (76-69). This is also supported by the results of data analysis of hypothesis testing, the test results obtained at $1 \%$ level with $\mathrm{n}=30$ obtained table $=2.46$ based on the calculation of the independent $t$ test, the results obtained tcount $=10.80$ and paired sample test 3.30 results obtained tcount. > t table, namely 10.80 and 3.30>2.46, it can be said to be very significant. So it can be concluded that there is a significant difference between student learning outcomes using the group investigation type cooperative learning model and the problem based learning model on learning outcomes of badminton forehand overhead lob.
\end{abstract}

Keywords: group investigation model, problem based learning model, cognitive learning outcomes, badminton, high school

\begin{abstract}
Abstrak
Latar belakang yang diperoleh, pembelajaran yang diterapkan belum mampu meningkatkan hasil belajar khususnya materi pukulan forehand lob permainan bulu tangkis, Penelitian ini menggunakan metode penelitian kuantitatif dengan menggunakan pendekatan eksperimen, desain yang digunakan dalam penelitian ini yaitu menggunakan desain quasi eksperimen, populasi dalam penelitian ini adalah siswa kelas X SMA Negeri 5 Semarang, teknik pengambilan sampel menggunakan random sampling. Sampel dalam penelitian diperoleh kelas X IPS 1 sebagai kelas eksperimen 1 dengan jumlah 30 siswa dan kelasX IPS 2 sebagai kelas eksperimen 2 dengan jumlah 30 siswa. Analisis data menggunakan uji validitas, uji reliabilitas, uji normalitas, uji homogenitas, dan uji t (uji banding). Berdasarkan hasil penelitian dan pembahasan diperoleh hasil belajar pukulan forehand overhead lob bulu tangkis dengan menerapkan model pembelajaran cooperative learning tipe group investigation diperoleh rata-rata nilai 69 dan penerapan model problem based learning diperoleh hasil rata-rata 76. Perbedaan antara hasil belajar siswa dengan menggunakan model pembelajaran cooperative learning tipe group investigation dan problem based learning berdasarkan rata-rata sebesar 7 poin (76-69). Hal ini juga didukung dengan hasil analisis data pengujian hipotesis diperoleh hasil uji t taraf $1 \%$ dengan $n=30$ diperoleh $\mathrm{t}_{\text {tabel }}=2,46$ berdasarkan perhitungan uji $\mathrm{t}$ independent didapatkan hasil $\mathrm{t}_{\text {hitung }}=10,80$ dan uji paired sampel $t$ test 3,30 hasilnya $\mathrm{t}_{\text {hitung }}>\mathrm{t}_{\text {tabel }}$ yaitu 10,80 dan 3,30>2,46 maka dapat dikatakan sangat signifikan. Maka dapat disimpulkan ada perbedaan yang signifikan antara hasil belajar siswa yang menggunakan model pembelajaran cooperative learning tipe group investigation dan model problem based learning terhadap hasil belajar pukulan forehand overhead lob bulutangkis.
\end{abstract}

Kata Kunci: model group investigation, model problem based learning, hasil belajar kognitif, bulu tangkis, SMA 


\section{PENDAHULUAN}

Pendidikan adalah salah satu wadah yang digunakan untuk menambah pengetahuan, kemampuan serta keterampilan dalam diri manusia sehingga berdampak membuat perubahan pola fikir, sifat serta gerak yang menuju kearah yang lebih baik. Pembelajaran pendidikan dan jasmani guru sering kali memberikan materi-materi pembelajaran pendidikan dan jasmani melalui cabangcabang olahraga, dan pemberian materi tersebut sudah diatur dalam KI KD kurikulum 2013. Berdasarkan observasi fenomena yang terjadi pada siswa di SMA Negeri 5 Semarang pada mata pelajaran pendidikan jasmani terutama dalam cabang olahraga bulu tangkis tentang pembelajaran materi pukulan overhead lob yang dilakukan siswa diperoleh informasi antara lain: (1) pembelajaran yang diterapkan belum mampu meningkatkan hasil belajar khususnya materi pukulan forehand lob permainan bulu tangkis, (2) kurangnya pemahaman siswa terhadap teknik pukulan overhead lob, (3) siswa masih bingung dengan teknik pukulan overhead lobyang tepat, dan (4) kurangnya variasi model pembelajaran yang diterapkan oleh guru dalam pembelajaran materi pukulan overhead lob. Hal tersebut dibuktikan dengan nilai siswa yang masih dibawah nilai KKM 75.

Permasalahan tersebut memerlukan model pembelajaran yang dapat meningkatkan hasil belajar materi pukulan forehand overhead lob bulutangkis siswa kelas X SMA N 5 Semarang. Salah satu upaya yang dilakukan untuk pembelajaran bulu tangkis khususnya hasil belajar materi pukulan forehand overhead lob bulu tangkis siswa kelas X SMA N 5 Semarang dengan menggunakan alternatif menerapkan model pembelajaran model Cooperative learning tipe group investigation dan Problem based learning dalam meningkatkan hasil belajar kognitif materi pukulan forehand overhead lob. Alasan rasional menggunakan model Cooperative learning tipe group investigation karena kemampuan siswa betul-betul dioptimalisasikan melalui kerja kelompok sehingga pembelajaran siswa diharapkan efektif dan memperoleh respon positif siswa yang mempengaruhi hasil belajar siswa lebih baik lagi.

\section{METODE}

Penelitian ini menggunakan penelitian kuantitatif. Penelitian kuantitatif adalah proses menemukan pengetahuan yang menggunakan data berupa angka sebagai alat menemukan keterangan mengenai apa yang ingin diketahui. Alasan digunakannya pendekatan kuantitatif adalah ingin memberi gambaran yang jelas mengenai pengaruh model pembelajaran cooperative learning tipe group investigation dan problem based learning terhadap hasil belajar pukulan forehand overhead lob bulutangkis siswa kelas X SMA Negeri 5 Semarang. Populasi penelitian ini adalah siswa kelas X SMA Negeri 5 Semarang tahun pelajaran 2020/2021 yang berjumlah 352 siswa yang terbagi menjadi 11 kelas yaitu 9 X IPA dan 2 kelas X IPS. Pada hal ini sampel dalam penelitian yang terpilih yaitu $\mathrm{X}$ IPS 1 dengan jumlah 30 siswa sebagai kelompok eksprimen 1 yang menggunakan model pembelajaran tipe group investigation dan X IPS 2 dengan 30 siswa sebagai kelompok eksperimen 
2 menggunakan model pembelajaran problem based learning. Untuk menganalisis data diperlakuakan suatu cara atau metode. Adapun uji persyaratan analisis validitas, reliabilitas, uji normalitas data, uji homogenitas data, uji hipotesis.

\section{HASIL PENELITIAN DAN PEMBAHASAN}

Penerapan model pembelajaran cooperative learning tipe group investigation terhadap hasil belajar kognitif pukulan forehand overhead lob bulu tangkis siswa kelas X SMA Negeri 5 Semarang dilakukan dengan secara daring melalui software Google Meet dengan langkah pertama guru mengorganisasikan siswa ke dalam kelompok, kedua guru merencanakan tugas-tugas belajar secara bersama-sama dengan siswa dalam kelompoknya yang dibagi oleh guru sebelumnya, ketiga melaksanakan investigasi guru mengarahkan siswa mencari informasi, menganalisis data, dan membuat kesimpulan secara kelompok daring, langkah keempat menyiapkan laporan akhir siswa menyiapkan rencana laporan sebagai bahan untuk dikirim via whatsapp, dan yang keenam evaluasi siswa berbagi informasi, ide, dan gagasannya kemudian guru memberi penguatan dengan mengevaluasi hasil kerja kelompok masing-masing dan menyimpulkan pelajaran pukulan forehand overhead lob bulu tangkis. Hasil belajar kognitif pukulan forehand overhead lob bulu tangkis siswa kelas X SMA Negeri 5 Semarang dengan menerapkan model group investigation diketahui nilai tertinggi 96 dan terendah 46 dengan rata-rata nilai 69.

Sementara itu, penerapan model pembelajaran problem based learning terhadap hasil belajar kognitif pukulan forehand overhead lob bulu tangkis siswa kelas X SMA Negeri 5 Semarang dilakukan juga dengan secara daring melalui software Google Meet dimulai dengan guru menyampaikan masalah yang akan dipecahkan, Guru memastikan peserta didik siap dalam belajar mengabsen dalam bentuk list didalam whatsapp group dan messenger group dan memastikan peserta didik untuk aktif dalam pelajaran daring, guru meminta peserta didik untuk mencari materi tentang pukulan forehand overhead lob bulu tangkis di internet, guru meminta peserta didik mengerjakan soal yang disampaikan di google form dan menyajikan hasilnya dengan cara mempost hasil pekerjaan mereka dalam whatsapp dan messenger group, guru meminta peserta didik untuk membuat kesimpulan terkait kegiatan yang dilakukan secara daring di whatsapp messenger. Kemudian guru memberikan evaluasi dan feedback sederhana berbentuk soal melalui whatsapp group. Berdasarkan penerapan model problem based learning diketahui nilai kelas eksperimen 2 diperoleh nilai tertinggi 96, terendah 46, dan rata-rata nilai 76.

Setelah melakukan analisis data penelitian,terdapat perbedaan antara hasil belajar siswa dengan menggunakan model pembelajaran cooperative learning tipe group investigation dan problem based learning pada materi pukulan forehand overhead lob bulutangkis siswa kelas X SMA Negeri 5 Semarang. Perbedaan tersebut terletak pada rata-rata dan frekuensi nilai.

Disisi lain, Sementara itu diketahui hasil uji normalitas data pretest kelompok kontrol diperoleh $\mathrm{L}_{\text {hitung }}=0,086$ dengan $\mathrm{n}=30$, dengan taraf nyata $\alpha=5 \%$ dari daftar nilai kritis $\mathrm{L}$ diperoleh 
nilai $\mathrm{L}_{\text {tabel }}=0,161$ maka $\mathrm{L}_{\text {hitung }}<\mathrm{L}_{\text {tabel }}$ yaitu $0,086<0,161$. Uji normalitas data pretest kelompok eksperimen 2 diperoleh $\mathrm{L}_{\text {hitung }}=0,140$ dengan $\mathrm{n}=30$, dengan taraf nyata $\alpha=5 \%$ dari daftar nilai kritis $\mathrm{L}$ diperoleh nilai $\mathrm{L}_{\text {tabel }}=0,161$ maka $\mathrm{L}_{\text {hitung }}<\mathrm{L}_{\text {tabel }}$ yaitu $0,140<0,161$. Sementara itu, pada uji normalitas posttest kelompok eksperimen 1 diperoleh $\mathrm{L}_{\text {hitung }}=0,107$ dengan $\mathrm{n}=30$, dengan taraf nyata $\alpha=5 \%$ dari daftar nilai kritis $\mathrm{L}$ diperoleh nilai $\mathrm{L}_{\text {tabel }}=0,161$ maka $\mathrm{L}_{\text {hitung }}<\mathrm{L}_{\text {tabel }}$ yaitu $0,107<0,161$. Uji normalitas data posttest kelompok eksperimen diperoleh $\mathrm{L}_{\text {hitung }}=0,093$ dengan $\mathrm{n}=30$, dengan taraf nyata $\alpha=5 \%$ dari daftar nilai kritis $\mathrm{L}$ diperoleh nilai $\mathrm{L}_{\text {tabel }}=0,161$ maka $\mathrm{L}_{\text {hitung }}<$ $\mathrm{L}_{\text {tabel }}$ yaitu 0,093<0,161.Maka H $\alpha$ diterima dan berdistribusi normal.

Perhitungan uji homogenitas diperoleh data pretest $\mathrm{F}_{\text {hitung }}=1,342404832$ dibulatkan menjadi 1,34 dan data posttest $\mathrm{F}_{\text {hitung }}=1,151654617$ dibulatkan menjadi 1,15. Dengan harga tabel taraf signifikan 5\%, diperoleh $\mathrm{dk}$ pembilang $=\mathrm{n}-1$ (untuk varians terbesar), dan $\mathrm{dk}$ penyebut $=\mathrm{n}-1$ (untuk varians terkecil) diperoleh $\mathrm{F}_{\text {tabel }}=3,33$. Jadi, dapat disimpulkan bahwa uji homogenitas data pretest dan posttest diperoleh $\mathrm{F}_{\text {hitung }}<\mathrm{F}_{\text {tabel }}$, yaitu $1,34<3,33$ dan $1,15<3,33$. Maka Ha diterima (populasi tersebut mempunyai varians yang homogen). Artinya, populasi tersebut mempunyai varians homogen.

Dari hasil uji $\mathrm{t}$ independent taraf $1 \%$ dengan $\mathrm{n}=30$ diperoleh $\mathrm{t}_{\text {tabel }}=2,46$ berdasarkan perhitungan uji $t$ didapatkan hasil $t_{\text {hitung }}=10,80$ hasilnya $t_{\text {hitung }}>t_{\text {tabel }}$ yaitu 10,80 $>2,46$ maka dapat dikatakan sangat signifikan. Sementara hasil uji Paired Sampel t-test diperoleh 3,30 hasilnya $t_{\text {hitung }}>t_{\text {tabel }}$ yaitu 3,30 > 2,46 maka dapat juga dikatakan sangat signifikan.

Jadi dapat disimpulkan bahwa ada perbedaan yang signifikan antara hasil belajar siswa yang menggunakan model pembelajaran cooperative learning tipe group investigation dan model problem based learning terhadap hasil belajar pukulan forehand overhead lob bulutangkis. Sehingga dapat dikatakan penggunaan model problem based learning lebih tepat digunakan pada pembelajaran pukulan forehand overhead lob bulutangkis pada siswa kelas X SMA Negeri 5 Semarang.

Hasil penelitian ini juga sesuai dengan penelitian yang dilakukan oleh Suwondo (2010) yang menyatakan bahwa terdapat peningkatan hasil belajar setelah penerapan model pembelajaran problem based learning. Hal ini tidak terlepas dari proses belajar yang terdapat dalam model problem based learning. Model problem based learning melibatkan siswa untuk memecahkan suatu masalah melalui tahapan-tahapan metode ilmiah sehingga siswa dapat mempelajari pengetahuan yang berhubungan dengan masalah dan sekaligus memiliki keterampilan untuk memecahkan masalah sehingga dapat mengembangkan kemampuan berpikir siswa dalam merancang suatu percobaan.

\section{PENUTUP}

Penelitian kelas X SMA Negeri 5 Semarang dapat disimpulkan sebagai berikut.

1. Penerapan model pembelajaran cooperative learning tipe group investigation dilakukan dengan secara daring melalui software Google Meet dengan langkah pertama membentuk kelompok, 
kedua merencanakan tugas, ketiga melaksanakan investigasi, langkah keempat menyiapkan laporan akhir, keenam evaluasi

2. Penerapan model pembelajaran problem based learning dilakukan dengan secara daring melalui software Google Meet dimulai dengan menyampaikan masalah, memastikan peserta didik siap dalam belajar, mencari materi, mempublikasian, membuat simpulan, dan evaluasi dan feedback sederhana berbentuk soal.

3. Perbedaan hasil hasil belajar pukulan forehand overhead lob bulu tangkis dengan menerapkan model pembelajaran cooperative learning tipe group investigation diperoleh rata-rata nilai dan perbedaan hasil belajar siswa dengan menggunakan model pembelajaran cooperative learning tipe group investigation dan problem based learning berdasarkan rata-rata sebesar 7 poin (76-69). Hal ini juga didukung dengan hasil analisis data pengujian hipotesis diperolehhasil uji t taraf $1 \%$ dengan $n=30$ diperoleh $t_{\text {tabel }}=2,46$ berdasarkan perhitungan uji $t$ didapatkan hasil $t_{\text {hitung }}=10,80$ hasilnya $t_{\text {hitung }}>t_{\text {tabel }}$ yaitu 10,80 $>2,46$ maka dapat dikatakan sangat signifikan. Maka dapat disimpulkan ada perbedaan yang signifikan antara hasil belajar siswa yang menggunakan model pembelajaran cooperative learning tipe group investigation dan model problem based learning terhadap hasil belajar pukulan forehand overhead lob bulu tangkis. Penerapan model problem based learning lebih tepat digunakan pada pembelajaran pukulan forehand overhead lob bulu tangkis pada siswa kelas X SMA Negeri 5 Semarang.

\section{DAFTAR PUSTAKA}

Abdul Majid.2015. Pendekatan Ilmiah dalam Implementasi Kurikulum 2013. Bandung: PT. Remaja Rosdakarya.

Abidin, Yunus. 2014. Desain Sistem Pembelajaran dalam Konteks Kurikulum 2013. Bandung: PT Refika aditama.

Acar, B \& L. Tarhan. 2007. Effects of Cooperative Learning on Students' Understanding of Metallic Bonding. Res Sci Educ, 38:401-420.

Agus. 2015. Cooperative Learning. Yogyakarta: Pustaka Belajar.

Ahmad, Z \& Mahmood, N. 2010. Effects of Cooperative Learning vs Traditional Instruction on Prospective Teacher Learning Experience and Achievement. Journal of Faculty of Educational Sciences. Vol. 43, No. 1, page: 151-164.

Alsaputra GB. 2015. Penerapan Model Pembelajaran Kooperatif Tipe GroupInvestigation (GI) Terhadap Peningkatan Hasil Belajar dan Kerjasama SiswaSMP (Skripsi). Semarang: Universitas Negeri Semarang.

Aprilia, Indri. 2015. Pengaruh Model Pembelajaran Kooperatif Tipe Group Investigation (Gi) Terhadap Hasil Belajar Siswa dalam Pembelajaran Biologi Pada Materi Ekosistem Di Kelas VII Semester II MTSn 1 Palangka Raya Tahun Pelajaran 2014/2015. Jurnal EduSains Volume 3 Nomor 2; ISSN 2338-4387. 
Penerapan Model Pembelajaran Cooperative Learning Tipe Group Investigation Dan Problem Based Learning Terhadap Hasil Belajar Kognitif Materi Bulutangkis Siswa Kelas X SMA Negeri 5 Semarang., Satrio Sembodo 327

Arikunto.2013.Prosedur Penelitian Suatu Pendekatan Praktik. Edisi Revisi.Jakarta: PT. Rineka Cipta.

Artini, M. Pasaribu \& M. Husain. 2015. Penerapan Model PembelajaranKooperatif Tipe Group investigation Untuk Meningkatkan Aktivitas danHasil Belajar Ipa Pada Siswa Kelas VI SD Inpres 1 Tondo. e-JurnalMitra Sains, 3(1).

Azwar.2012. Reliabilitas dan Validitas.Yogyakarta: Pustaka Pelajar

Dasna, I.W. dan Sutrisna. 2010. Pembelajaran Berbasis Masalah (Problem-Based Learning). Malang: Universitas Negeri Malang

Dewi, R., R. S. Iswari \& R. Susanti. 2012. Penerapan Model Group investigationTerhadap Hasil Belajar Materi Bahan Kimia di SMP. Unnes Science Education Journal.

Estiani, W., A. Widiyatmoko \& Sarwi. 2015. Pengembangan MediaPermainan Kartu Uno Untuk Meningkatkan Pemahaman Konsep danKarakter Siswa Kelas VIII Tema Optik. Unnes Science Educational Journal, 4(1).

Fandiono. 2013. Kemampuan Dasar Pukulan Lob Peserta Ekstrakurikuler Bulu Tangkis Kelas V Sekolah Dasar Negeri 2 Klapasawit Kecamatan Kalimanah Kabupaten Purbalingga Tahun Ajaran 2012/2013.Skripsi. Fakultas Ilmu Keolahragaan Universitas Negeri Yogyakarta.

Fathurrohman,Muh. 2017. Model-Model Pembelajaran Inovatif: Alternatif Desain Pembelajaran yang Menyenangkan. Jogjakarta:Ar-Ruzz Media

Huda, Miftahul. 2014. Cooperative Learning. Pustaka Pelajar. Yogyakarta.

Husdarta. 2011. Manajemen Pendidikan Jasmani. Bandung : Alfabeta

Kurniawan A. 2015. Keefektifan Model Pembelajaran Group Investigation Berbasis Eksperimen Terhadap Academic Skill dan Penguasaan Konsep Siswa pada Materi Kalor (Skripsi). Semarang: Universitas Negeri Semarang.

Maksum. 2012. Metodologi Penelitian. Surabaya: Unesa University Press.

Nurdin, Ujang. 2010. Kelebihan dan Kekurangan Model Group Investigation. Online. Avaible at http://discussion-lecture.blogspot.com/2012/09/ pembelajaran.html. (accessed 24/02/15).

Nurdwi.2019. Tingkat Keterampilan Teknik Dasar Servis Dalam Permainan Bulu Tangkis Pada Atlet PB. Karsa Mandiri Makassar.Jurnal

Poole. 2016. Belajar Bulu tangkis. Bandung: Pionir Jaya.

Pujianto.2012. Modifikasi Pegangan Raket untuk Meningkatkan Kemampuan Teknik Pegangan Bulu tangkis." Jurnal Media Ilmu Keolahragaan IndonesiaVol. 2.

Purnama. 2010. Kepelatihan Bulu tangkis Modern. Surakarta: Yuma Pressido

Purnomo. 2017. Penerapan model cooperative learning tipe group investigation terhadap hasil belajar servis lob bulu tangkis.Jurnal

Purwanto. 2014. Evaluasi Hasil Belajar. Yogyakarta: Pustaka Pelajar 
Raharjo. 2014. "Penerapan Media Audio visual (video) terhadap hasil belajar over head lob dalam pembelajaran bulu tangkis (Studi pada siswa SMP Negeri 26 Surabaya)."Jurnal Pendidikan Olahraga dan Kesehatan Vol.02 No. 03.

Rusman.2014. Model-model Pembelajaran (MengembangkanProfesionalisme Guru). Jakarta: Raja GrafindoPersada

Saefullah\&Sudaryono. 2012. Statistik Deskriptif - Langkah Mudah Analisis Data. Yogyakarta: C.V Andi Offset.

Sanjaya, W. 2010. Strategi Pembelajaran Berorientasi Standar Proses Pendidikan. Jakarta: Kencana.

Sari, D.D. 2012. Penerapan Model Problem Based Learning (PBL) Untuk Meningkatkan Kemampuan Berpikir Kritis Peserta Didik Pada Pembelajaran IPA Kelas VIII SMPN 5 Sleman. Skripsi UNY. Yogyakarta.

Slavin, Robert E. 2014. Cooperative Learning, Teori, Riset dan Praktik. Bandung: Nusa Media.

Sudjana \& Ahmad. 2013. Media Pengajaran. Bandung: Sinar BaruAlgensindo.

Sudjana. 2016. Penilaian Hasil Proses Belajar Mengajar. Bandung: Remaja Rosdakarya.

Sugiyono. 2013. MetodePenelitianKuantitatif, Kualitatifdan R\&D. Bandung:Alfabeta.

Sukmadinata, N.S. 2017. Metode Penelitian Pendidikan. Bandung: PT. Remaja Rosdakarya.

Sulaksana. 2017. "Pengaruh penggunaan metode net miring terhadap ketepatan smash di sekolah bulu tangkis Natura Prambanan Klaten.” Skripsi. Fakultas Ilmu Keolahragaan Universitas Negeri Yogyakarta.

Sumantri, Mohamad Syarif. 2015. Strategi Pembelajaran, Teori dan Praktik di Tingkat Pendidikan Dasar. Jakarta: Rajawali Pers.

Suparmi. 2012. Pembelajaran Kooperatif dalam Pendidikan Multikultural. Jurnal Pembangunan Pendidikan: Fondasi dan Aplikasi. Volume 1. Nomor 1.

Veristika, Nela dkk. 2012. Penerapan Model Pembelajaran Group Investigation untuk Meningkatkan Keaktifan dan Hasil Belajar Siswa pada Pokok Bahasan Mengelola Kompetensi Personal di SMK Negeri 1 Kudus (Studi pada Kelas X Pemasaran 3 Tahun Pelajaran 2011/2012). Economic Education Analysis Journal 1/1:3.

Wahyudi, Yulianti D \& Putra NMD. 2012. Upaya mengembangkan learning community siswa kelas X SMA melalui penerapan model pembelajaran kooperatif tipe STAD berbasis CTL pada pembelajaran Fisika. Jurnal Pendidikan IPA Indonesia 1:57-62.

Wahyuningsih, I., Sarwi \& Sugianto. 2012. Penerapan Model Kooperatif GroupInvestigation Berbasis Eksperimen Inkuiri Terbimbing Untuk MeningkatkanAktivitas Belajar. Unnes Physics Educational Journal. Tersedia di http://journal.unnes.ac.id/sju/index.php/upej

Wibisono, dkk. 2017. Pembelajaran Kooperatif Sebagai Upaya Meningkatkan Motivasi, Empati dan Perilaku Bekerjasama. SCHEMA-Journal of Psychological Research, Vol. 1.

Widjajanti.2011. Problem-Based Learning dan Contoh Implementasinya. http://staff.uny.ac.id/sites/default/files/tmp/PPM-PBL $\% 2010 \% 20$ Maret\%202011Djamilah.pdf. Makalah. (Diakses tanggal 6 Maret 2020). 